Wacław Lewandowski

\section{Biografia Leopolda Tyrmanda}

DOI: http://dx.doi.org/10.12775/LC.2017.045
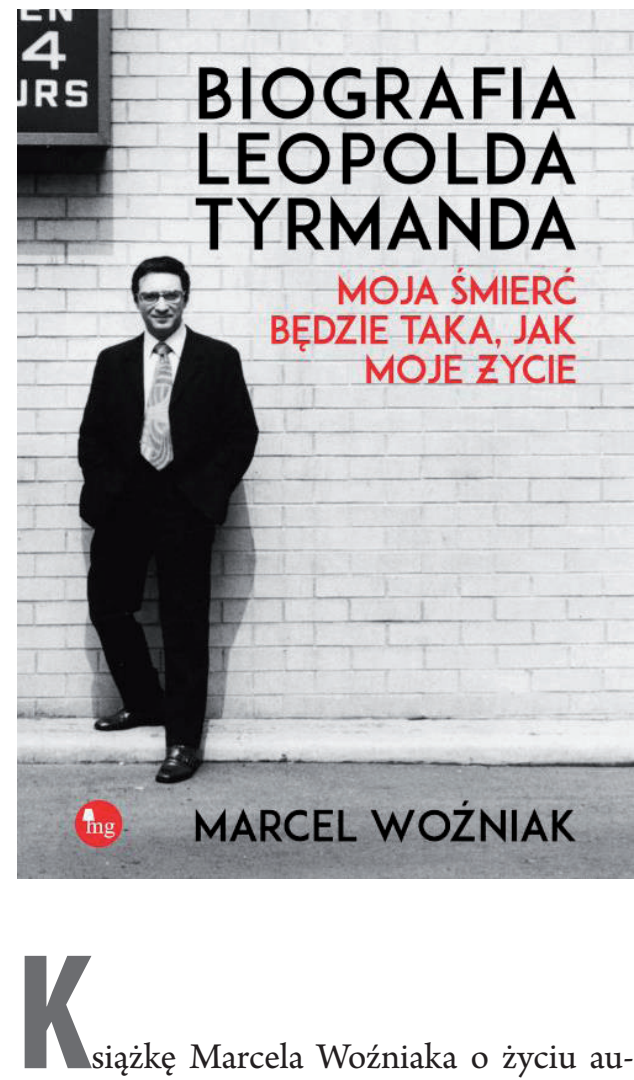

siążkę Marcela Woźniaka o życiu autora Złego poprzedza przedmowa, w której syn pisarza, Matthew Tyrmand, nazywa ją pierwszą źródłową biografią swego ojca i gorąco rekomenduje czytelnikom, z dumą - jak powiada - się pod nią podpisując. M. Tyrmand zapewnia, że dzieło Woźniaka różni się od wszystkich dotąd powstałych biografii jego ojca, bo jego au-

* Profesor w Instytucie Literatury Polskiej Uniwersytetu Mikołaja Kopernika w Toruniu; historyk literatury, edytor. E-mail: waclaw@umk.pl. tor „miał śmiałość i wizję pełnego oglądu życia” pisarza. Przyznam, że choć zgadzam się z Tyrmandem-juniorem, że poprzednie biografie Leopolda Tyrmanda „nie były szczególnie zadowalające”, jednak zaniepokoił mnie jego entuzjazm dla biografii najnowszej. Małoż to razy zdarzało się, iż rodziny pisarzy prowadziły ich biografów za rękę, tak by powstał wizerunek życia i osobowości pisarza zgodny z wolą i wyobrażeniem bliskich, niekoniecznie zaś zgodny z rzeczywistością i prawdziwy? - Są to rzeczy powszechnie znane, nic więc dziwnego, że do lektury przystąpiłem z ostrożną nieufnością, szybko jednak przekonałem się, że nie mamy tu do czynienia z sugestywnym „wgrywaniem” biografowi obrazu życia pisarza przez zainteresowaną pożądanym efektem rodzinę, a z czymś zgoła przeciwnym. Książka Woźniaka nie jest bowiem wyłącznie biografią Leopolda Tyrmanda, jest także opowieścią o tym, jak biograf stopniowo zapoznawał bliskich pisarza z jego dziejami, przeżyciami i doznaniami, odsłaniając nieznane dotąd rodzinie fakty i zdarzenia.

Marcel Woźniak wykonał potężną pracę archiwalną, odwiedzając niemal wszystkie miejsca, w które los rzucał pisarza, szukając śladów po nim, dokumentów i relacji świadków. W niektóre z tych miejsc dotarł jako pierwszy - np. jako pierwszy z piszących o życiu Tyrmanda sprawdził zasoby archiwów norweskich, odnajdując $\mathrm{w}$ nich potwierdzenia wojennych epizodów z życia pisarza, które dotąd uznawano za fikcję literacką lub mitotwórcze bajania samochwała-skandalisty. Woźniak skrupulatnie udokumentował wojenne przygody pisarza, dowodząc że jego powojenne opowiadania, jak i powieść Filip oparte były na faktach biograficznych, na autentycznych przeżyciach i doznaniach. Rzeczywisty Leopold Tyrmand, nie tylko jego wymyśleni literaccy bohaterowie, podał się za 
bezpaństwowca narodowości francuskiej i zgłosił na roboty do Niemiec, mieszkał w Moguncji, Wiesbaden, Frankfurcie nad Menem i Wiedniu, bywał tłumaczem, kreślarzem, bibliotekarzem, kelnerem i posługaczem hotelowym, stewardem na okręcie, z którego chciał zbiec do Szwecji, ale ujęty, został osadzony $\mathrm{w}$ norweskim obozie w Grini. Woźniak dokumentuje też romanse Tyrmanda $\mathrm{z}$ tego czasu - erotyczne związki z Niemkami ukrywającego się w Niemczech, w samym oku cyklonu Żyda okazują się prawdą, nie zmyśleniem czy legendą. Niektóre z zespołów archiwalnych wykorzystanych przez Woźniaka inni „tyrmandolodzy" przeglądali przed nim, np. pudła z papierami po Tyrmandzie w Archiwach Hoovera Uniwersytetu Stanforda otwierano wcześniej, ale to Woźniak jako pierwszy potrafił ogarnąć całą ich zawartość, uwzględnić każdy dokument i powiązać go z odpowiadającymi mu zdarzeniami. Nikt wcześniej nie opisał tak szczegółowo podróży pisarza do Izraela, nikt nie potwierdził prawdziwości jego wyznania, że do USA dotarł drogą morską, nikt wreszcie - by zostać przy tych kilku przykładach - nie wspomniał, że pracującego w Rockford Institute i wydającego tam „Rockford Papers” i „Chronicles of Culture" Tyrmanda docenil prezydent Ronald Reagan, zapraszając go w podróż do Chin z grupą czołowych amerykańskich pisarzy, że nadano mu medal imienia George'a Washingtona oraz medal agencji USIA za wybitne zasługi na polu dziennikarstwa. Przed Woźniakiem piszący o Tyrmandzie powielali rozpowszechniony przez Jerzego Giedroycia pogląd, jakoby pisarz w USA zmarnował się, pogrążył w nieróbstwie i związał z ultrakonserwatywnym prowincjonalnym ośrodkiem naukowym o marginalnym znaczeniu. Nota bene, Woźniak opisując nieudaną próbę współpracy Tyrmanda z Giedroyciem i niechęć redaktora „Kultury” do pisarza, potrafił nie powtarzać argumentów żadnej ze stron konfliktu, rzeczowo i przekonująco dowodząc, że był on nieuchronny i miał ideologiczne podłoże.

W rozdziale Księgi Tyrmandowe Woźniak zrekonstruował drzewo genealogiczne warszawskiej żydowskiej rodziny Tyrmundów (Tirmanów, Tyrmandów) od roku 1776. Narracja w tym rozdziale stylistycznie nawiązuje do genealogii starotestamentowych patriarchów. Woźniak postarał się, by każdy z rozdziałów książki był odrębny tematycznie i stylistycznie. Istotną pochodną tej koncepcji są powtórzenia $\mathrm{w}$ różnych rozdziałach mówi się o tych samych zdarzeniach, ale w innym ujęciu, $\mathrm{z}$ innej perspektywy, zgodnej z tematyką danej części. Pogłębia to ogląd zdarzeń, a także nie pozwala monotonii wkraść się do wywodu.

Woźniak jest zafascynowany Tyrmandem, jego umiłowanie tej postaci nie jest jednak ślepym uczuciem. Tyrmand portretowany jest tu ze wszystkimi zaletami, ale i wadami. Biograf potrafi, np., pokazać pisarza jako nieznośnego męża, niszczącego psychicznie żonę (Małgorzatę Żurowską), jako żądnego sławy megalomana i chwalipiętę, notorycznego egocentryka. Niektóre z tych wad bardzo mocno zaciążyły na życiu pisarza. Gdy czytamy o długich staraniach Tyrmanda o paszport, o jego pragnieniu ucieczki od komunizmu i wyjazdu do USA, w oczywisty sposób stajemy przed pytaniem, dlaczego nie został na Zachodzie w 1957 roku, kiedy to po raz pierwszy wypuszczono go z PRL, zezwalając na podróż do Londynu. Poleciał tam z ówczesną żoną, córką Ludwika Rubla, przez którego miał dostęp do elit „polskiego Londynu”. Mógł wówczas „wybrać wolność”, unikając niedogodności i represji, które czekały go w następnych latach. Woźniak przedstawia Tyrmanda w taki sposób, że nietrudno znaleźć odpowiedź na powyższe pytanie. Czas krótkiej popaździernikowej „odwilży” był 
bardzo łaskawy dla pisarza. Wydał Złego i U brzegów jazzu, odniósł sukces literacki i finansowy, stał się popularny, osiągnął wymarzoną sławę. Był optymistą, nie zakładał, że sytuacja gwałtownie się zmieni. Wrócił do Warszawy właśnie dla tej sławy i popularności, których zawsze był głodny.

W bardzo zajmujący i rozważny sposób przedstawia Woźniak wileński epizod życiorysu Tyrmanda. Odnosząc się do zarzutów Franciszka Walickiego, dotyczących współpracy pisarza z „Prawdą Komsomolską”, przytomnie zauważa, że Tyrmand, owszem, w „Prawdzie” pracowal, ale równocześnie działał w konspiracji, zaś Walicki nie konspirował, ale pracował $\mathrm{w}$ tej samej gazecie. Ważną jest też informacja, że właściwie nie wiadomo, co Tyrmand pisał do „Prawdy Komsomolskiej”. Tekstów nie podpisywał, wszystko zaś, co tam drukowano, szło do druku dopiero po przeredagowaniu przez naczelnego redaktora. Jest możliwe, że pisarz był tam zatrudniony głównie dla potrzeb korekt językowych - gazeta była przeznaczona dla Polaków, a w redakcji brakowało ludzi dobrze władających polszczyzną. Oczywiście, zatrudnienie w sowieckiej gazecie chluby nie przynosi, jest jednak faktem, że Tyrmand działał w konspiracji, w końcu został aresztowany przez NKWD i skazany i - gdyby nie wybuch wojny niemiecko-sowieckiej - zostałby z Wilna wywieziony w głąb Związku Sowieckiego (niemiecki nalot umożliwił mu ucieczkę z pociągu). Niezwykle interesująca jest również kwestia okoliczności aresztowania - wiele wskazuje na to, że Tyrmand-konspirator padł ofiarą prowokatora i sowieckiego agenta, Babinicza. Woźniak przeglądał w Wilnie akta sprawy Tyrmanda, nie znalazł $w$ nich jednak potwierdzenia roli Babinicza. W wywód na temat działania pisarza w ZWZ wkradł się jeden błąd - Tyrmand nie mógł złożyć konspiracyjnej przysięgi „w ruinach kościoła św. Piotra i Pawła” w Wilnie (s.95), bo ta piękna barokowa świątynia nigdy nie była $\mathrm{w}$ ruinie. Zapewne jest to przejęzyczenie. Poważniejszym błędem jest, natomiast, przyjęcie poglądu Franciszka Walickiego, jakoby w połowie czerwca 1940, gdy Wilno stało się stolicą sowieckiej republiki, nastąpiło odrodzenie polskiego szkolnictwa i polskiej kultury (s. 89). Po przytoczeniu wypowiedzi Walickiego Woźniak komentuje:

Rosjanie zaś mieli dwa oblicza. NKWD dokonywało czystek i mordów, ale tam, w Wilnie, przywrócono polskie szkoły, teatry i gazety, zamknięte uprzednio przez Litwinów. (s. 93)

- Jest to klasyczny błąd, polegający na zignorowaniu faktu, że przywracanie nauczania i wydawnictw w językach narodowych na zagarniętych obszarach było stałą sowiecką praktyką propagandową. Nie można więc pisać o przywróceniu polskich szkół czy gazet, a jedynie o wprowadzeniu sowieckich treści nauczania w języku polskim i wydawaniu sowieckiej prasy polskojęzycznej. Zwykle o „rozkwicie kultury polskiej" w sowieckim Wilnie w tamtym czasie mówili ci, którzy z tą sowiecką prasą $\mathrm{w}$ języku polskim (lub sowieckim teatrem po polsku) kolaborowali. Woźniakowi zdarza się jednak odczytywanie tekstów wspomnieniowych $\mathrm{z}$ pominięciem kontekstu historycznego. Np., gdy cytuje wspomnienia Jerzego Pańskiego, który organizował repatriację polskich displaced persons, tzw. Dipisów z Norwegii, pozostawia bez komentarza następujący fragment:

Przedstawiciele aliantów zachodnich wcale nie pragnęli repatriacji uchodźców do kraju. Zamierzali oni nastraszyć uchodźców trudnościami życia w Polsce i zaproponować im wyjazd do Australii, Kanady... Wysłannicy „rządu” emigracyjnego prowadzili już robotę informacyjną $\mathrm{w}$ obo- 
zach, namawiając do wyjazdu na Zachód. (s. 156)

Tego rodzaju wizja rzeczywistości w obozach dipisów pochodzi wprost z arsenału komunistycznej propagandy. Pański był komunistycznym dyplomatą, który tej propagandzie służył. Istnieje bogata literatura naukowa na temat agitacji na rzecz repatriacji, jaką UNRRA prowadziła w obozach dipisów. Między bajki można włożyć opowieści o „emisariuszach” emigracyjnego rządu, czy zachętach zachodnich rządów do emigracji. Istnieje także piękne literackie świadectwo na ten temat - Obóz Wszystkich Świętych Tadeusza Nowakowskiego.

Błędów rzeczowych jest w książce więcej. Na s. 291 mówi się o „zamknięciu PAX-u” w 1956, co nie miało miejsca. Na s. 297 czytamy, że Barbara Hoff „była młodsza od Lolka o dwanaście lat"; na s. 300: "gdy się pobierali on miał trzydzieści lat, ona - dwadzieścia siedem”. Na s. 315 mowa o „Klubie Inteligencji Krakowskiej”, gdy chodzi o Klub Inteligencji Katolickiej (KIK) w Krakowie. „Broń” po rosyjsku to „oruże”, nie „orużio” (s. 96), zaś zdania „oruże u was jest?” nie da się przetłumaczyć: „czy chowasz tu jaką́s broń”, a wyłącznie: „czy ma pan broń".

Kiedy Woźniak opowiada o wierszach, pisanych przez Tyrmanda w czasie wojny w Niemczech, zawodzi go słuch literacki.
Jedną ze strof odczytuje z rękopisu w sposób następujący (s. 124):

Wciąż cóż wybrać, sławę-życie

Ciężki ćwiek to do wybiera

Chce się sławy, chce się życia

Jedno $\mathrm{z}$ drugim walczy skrycie

Taka lekcja zabija i sens i rym. Na szczęście w książce jest fotografia rękopisu wiersza. Z łatwością można przeczytać:

Więc cóż wybrać, sławę - życie

Ciężki ćwiek to do wybicia

Chce się sławy, chce się życia

Jedno z drugim walczy skrycie.

Nie będę wyliczał oczywistych literówek i błędów zapisu - tych jest w książce sporo, najwyraźniej korekta była niedostateczna. Wszelkie niedomagania nie są jednak w stanie podważyć wartości tej pracy. Powstała bowiem biografia źródłowa, ukazująca wszelkie doświadczenia pisarza, które budowały jego pisarski potencjał. Te, które weszły w porządek jego twórczości i te, które wejść mogły, lecz nie zostały wykorzystane. Tego rodzaju biografia pisarza będzie pomocna historykom literatury, niezależnie od tego, że pozostanie ciekawą, pasjonującą książką dla szerokiej publiczności.

Marcel Woźniak, Biografia Leopolda Tyrmanda: moja śmierć będzie taka, jak moje życie, Wydawnictwo Mg, Kraków 2016, 461 ss. 